\title{
The Various Scenarios of Stock Exchange Development in Uzbekistan: in the Context of COVID-19
}

\author{
Dilbar Rustamova
}

\begin{abstract}
With increasing volatility in stock markets, the investment expectations of various market participants remain unclear. This study examines the short-term market development scenarios provided by international consulting companies. Inertial and optimistic scenarios of the national stock market are also presented as a result of the author's research. Several factors influencing the market index were also studied using a regression model, and as a result, the impact of factors such as market turnover, number of transactions, inflation rate on market capitalization was presented.
\end{abstract}

Index Terms - stock market, capitalization, volatility, optimistic scenario, inertial scenario.

\section{INTRODUCTION}

Analysis and forecasting of the current state of international and national financial markets and their development trends require, first of all, taking into account the effects of the emerging pandemic. Daily economic information provides information on serious negative changes or instability in various international stock markets. The disease has caused great health concerns around the world. However, concerns about economic consequences are growing as households need to stay home to slow the spread of the virus. It is unknown how the chain of influence that "suspends" the economy will affect household demand and the financial stability of the economy [1].

As the current situation is unprecedented and evolving rapidly, the economic models used in the study of macroeconomic fundamentals may be useful in market forecasting. It has been scientifically recognized that variable asset prices can be beneficial to most investors because they reflect investors 'expectations for future payments [2]. Therefore, for these potential investors, the stock and bond markets and credit markets can be the main starting point for making investments [3].

With the announcement of the COVID-19 pandemic by the World Health Organization, restrictions on economic activity began to be reflected in the stock market very quickly. In particular, the international stock market indices have been declining sharply since March this year. The U.S. NASDAQ index fell 23.05 percent, the S\&P 500 index fell 26.14 percent, the Dow Jones index fell 29.27 percent, and the NYSE index fell 31.23 percent. These negative indicators were soon reflected in the European financial market indices. These fluctuations are causing alarming observations among investors and various market participants. In particular, the
Euro Stocks 50 index fell 25 percent. GDP growth forecasts for next year are down 2.6 percent in both the US and the EU. We note that these calculations are based on a forecasting model using historical data. In abnormal periods, there is a risk of breaking the historical link between fund asset growth and asset valuations, i.e., these assumptions are accompanied by uncertainty [5] in the scientific literature.

\section{REVIEW OF THE LITERATURE ON THE SUBJECT}

The study examined various legal frameworks for overcoming the economic situation caused by the COVID-19 pandemic in Uzbekistan. In particular, the government measures to mitigate the negative impact of the coronavirus pandemic and the global crisis on sectors of the economy.

Online resources such as RSE "Tashkent" www.uzse.uz, www.fondbozori.uz, data of international stock markets www.weforum.org,www.marketwatch.com,

www.market.businessinsider.com were studied as a database for analysis.

In illuminating the theoretical-conceptual aspects of the study [1]-[3], [8]-[10] and other similar literature were studied.

\section{ANALYSIS AND RESULTS}

The McKenzie and Morgan Stanley presented different short-term scenarios of market development [4]. Below we review the most important points from these scenarios.

First, the optimistic scenario: rapid economic recovery. McKenzie estimates that measures to prevent the spread of the virus are effectively managed in the United States, as in most European countries, as in China. The spread of COVID19 slows down under the influence of quarantine efforts (measures such as remote work, travel restrictions, fencing for the elderly). Under this scenario, the economic crisis in the U.S. and Europe is expected to end by the end of March 2021. The Chinese stock market, by this time, was expected to recover from the market crash that occurred in late April 2020 [4].

Another research by Morgan Stanley, estimates that the S\&P 500 index, which collapsed in 2020 as a result of the pandemic, will reach $3,250 \mathrm{bp}$. was expected to return to the pre-Covid level. In the first quarter of 2020, global economic growth slowed to 2.5 percent, but from the second quarter onwards, the economy will begin to recover. At the end of this year, it was predicted that assets in the stock market could 
lead to a rise in prices [4].

Second, the middle scenario: uncertainty and the risk of stagnation. McKenzie predicted that in this scenario, the spread of the coronavirus could have a serious impact on the health system in the U.S., Europe, and other countries, but it was predicted that the rate of infection would slow as the temperature rose. Officials were expected to impose increasingly severe restrictions on economic activity, leading to a slowdown in economic growth that continued into the second quarter. It was predicted that the economic situation in the tourism sector could worsen in sectors such as air travel. The world economy is expected to recover from the recession in the second half of the year, but global economic growth is expected to slow to $1-1.5$ percent. Under this scenario, the U.S. economy is projected to grow at less than 1 percent per year, and China's GDP growth at less than 4 percent per year [4].

Finally, a worrying scenario: the continuation of the pandemic both during the summer and the global crisis. According to McKenzie's analysis, if the global spread of the virus continues into the third quarter, the global economy is expecting a serious blow that will last almost a year. The stagnation in the economy and the overload in the health care system of the countries could lead to a global crisis. Thus, in 2020 the economic growth rate will be minimal - from 0.5 percent to 1 percent. In particular, according to him, the growth of US GDP in the first half of 2020 will be close to 0 percent. The S\&P 500 index could end the year at around $2750 \mathrm{bp}$. However, during the panic among investors, it is estimated that this figure is likely to fall again.

It also estimates that a long-running pandemic could cause about 1 billion people to become infected with the coronavirus, according to this pessimistic forecast. Nevertheless, waiting for the vaccine in 2021 and the emergence of effective treatment will prevent general panic. In this scenario, the Dow Jones, the S\&P 500, and the NASDAQ were projected to fall by a third.

In the current situation in June-July of 2020, we can see that the pandemic continues, the level of economic activity is still low, and at the same time, as a result of financial support from national governments, some economic indicators have shown a positive trend. In particular, the S\&P 500 has its lowest 2,237 bp. (March 23, 2019) and 3,115 bp. (July 1, 2019) and the NASDAQ, 6,860 bp. (March 20, 2019) and 10,154 bp. (July 1, 2020) [2], [6], [7].

In March 2020, quarantine measures in Uzbekistan impacted the market index of RSE "Tashkent", which led to a sharp drop in the price of shares of enterprises and banks with large capitalization in the stock market.

Analyzing the stock market index, the following picture shows that the period of COVID-19 infection in our country has a strong fluctuation (Fig. 1).

According to the results of the first quarter of 2020, the capitalization of joint-stock companies listed in RSE "Tashkent" decreased by $4.06 \%$. That is, the total capitalization at the beginning of the quarter amounted to 52.50 trillion. At the end of the quarter, it amounted to 50.37 trillion soums. The highest figure in the period under review was recorded at the end of January, reaching 53.16 trillion. soums[10].

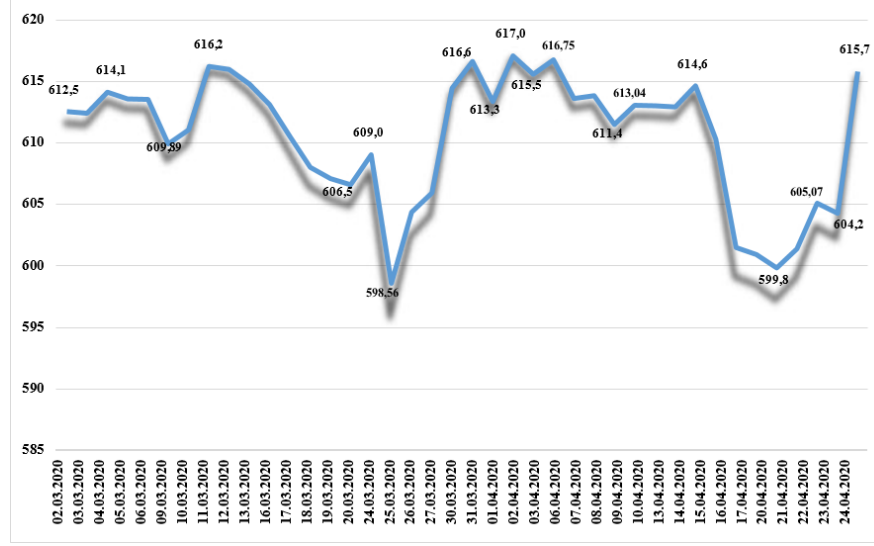

Fig. 1. Market situation of the RSE index "Tashkent” in March-April 2020 [9].

During the study, several factors affecting the level of capitalization of the stock market of Uzbekistan in the period from 210 to 2019 were studied to explain in many ways the volatility that occurred in the country during the pandemic. In particular, the effect on capitalization was modeled using the following regression equation and certain results were obtained.

The following factors influencing the capitalization of the stock market during the period under review were:

$\mathrm{Y}$ - market capitalization at the end of the month (bln. soums); X1 (Monthly volume of stock market turnover (bln. soum) - the monthly volume of stock market turnover (bln. soum); X2 (Average daily volume of stock market turnover (bln. soum)) - average volume of the daily turnover of the stock exchange (bln. Sum); X3 Quantity of market deals, Monthly - number of stock market transactions, monthly; X4 (Quantity of listed joint-stock companies traded in the stock market during the month) - number of joint-stock companies traded on the stock exchange; X5 (investment) - total investment in the republic volume (billion soums); X6 (export) - the volume of exports in the country during the year (thousand US dollars); X7 (average inflation rate) - the average inflation rate (percent); X8 (GDP) - the annual GDP of the republic (thousand U.S. dollar.) Was selected.

TABLE 1: A DESCRIPTIVE INTERPRETATION OF THE FACTORS INFLUENCING THE REGULATION OF THE STOCK MARKET

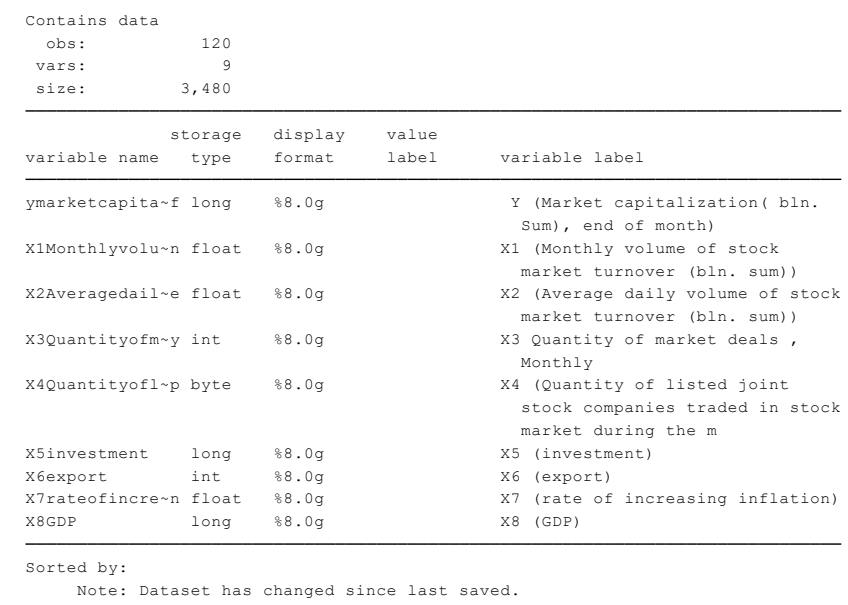

According to research, the investment attractiveness of companies that have recently put their shares on IPO is 
determined by the financial stability of the company and the export orientation of its products. Consequently, as it was not possible to obtain data on the volume of exports of enterprises whose shares were traded, the econometric model included data on the volume of exports in the country.

During this study, 8 factors were studied and a total of 120 observations were made. We can see the distribution of the collected data in Table 2 below. We test the distribution of the sample data on Skewness and Kurtosis and determine the adequacy of the sample. Only, with the number of joint-stock companies traded on the stock exchange, the r-value of inflation data was found to be greater than 0.05 .

TABLE 2: DISTRIBUTION OF DATA COLLECTED ON FACTORS INFLUENCING
$\begin{array}{r}\text { STOCK MARKET REGULATION } \\
\text { Skewness/Kurtosis tests for Normality }\end{array}$
\begin{tabular}{r|rcccc} 
Variable & Obs & Pr(Skewness) & Pr(Kurtosis) adj chi2(2) & Prob>chi2 \\
\hline ymarketcap $\sim \mathrm{f}$ & 120 & 0.0000 & 0.0000 &. & 0.0000 \\
X1Monthlyv n & 120 & 0.0000 & 0.0000 &. & 0.0000 \\
X2Averaged e & 120 & 0.0261 & 0.3215 & 5.73 & 0.0570 \\
X3Quantity y & 120 & 0.0000 & 0.0000 & 67.93 & 0.0000 \\
X4Quantity p & 120 & 0.0202 & 0.7989 & 5.36 & 0.0687 \\
X5investment & 120 & 0.0000 & 0.1715 & 20.76 & 0.0000 \\
X6export & 120 & 0.0000 & 0.0000 &. & 0.0000 \\
X7rateofin n & 120 & 0.0000 & 0.2455 & 16.78 & 0.0002 \\
X8GDP & 120 & 0.0000 & 0.0000 &. & 0.0000
\end{tabular}

We formulate a hypothesis based on the purpose of the study and the data collected. To determine the relationship between factors, we determine the correlation coefficient, and for this, we construct a correlation matrix.

A Pearson correlation matrix was constructed to determine the double correlation coefficient of the factors influencing the stock market capitalization and to check the adequacy of the correlation.

TABLE 3: CORRELATION COEFFICIENT OF FACTORS AFFECTING STOCK

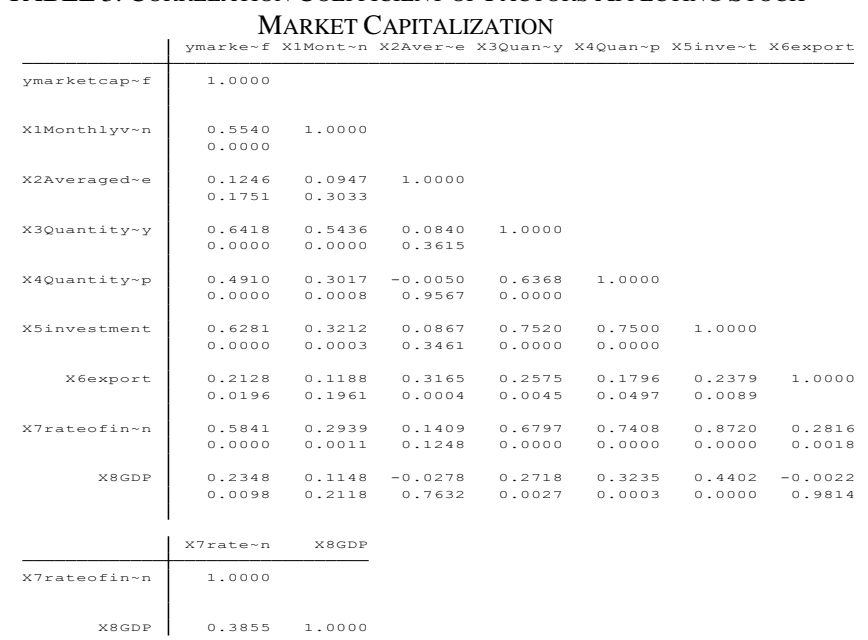

The general regression equation of the equation is as follows:

$$
\begin{gathered}
\mathrm{Y}=1,19 \mathrm{X} 1+603,11 \mathrm{X} 2+3,8 \mathrm{X} 3- \\
94,3 \mathrm{X} 4+0,2 \mathrm{X} 5+0,32 \times 6+864,2 \times 7-0,002 \times 8-16271,4
\end{gathered}
$$

The results show a $1 \%$ increase in monthly turnover in the stock market increases stock market capitalization by $0.13 \%$, a $1 \%$ increase in the number of transactions increases stock market capitalization by 0.16 units, and a $1 \%$ increase in inflation in the country increases stock market capitalization by 1.09 units.

Based on the results of the above model, an inertial scenario of the market capitalization forecast was constructed. Also, an optimistic scenario of stock market development was presented on an exponential trend.

TABLE 4: REgRESSION EQUATION OF All FACTORS AFFECTING STOCK

\begin{tabular}{|c|c|c|c|c|c|}
\hline Source & ss & df & MS & Number of obs & $=$ \\
\hline Model & $3.7546 \mathrm{e}+10$ & 8 & $4.6933 \mathrm{e}+09$ & Prob > F & $=$ \\
\hline Residual & $3.1084 \mathrm{e}+10$ & 111 & 280037154 & R-squared & $=$ \\
\hline Total & $6.8630 \mathrm{e}+10$ & 119 & 576724010 & Root MSE & $=$ \\
\hline
\end{tabular}
MARKET CAPITALIZATION

\begin{tabular}{r|rrrrrr}
\hline ymarketcap f & Coef. & Std. Err. & $\mathrm{t}$ & P>|t| & [95\% Conf. & Interval] \\
\hline X1MonthlyV $\sim \mathrm{n}$ & 1.190978 & .2699401 & 4.41 & 0.000 & .656074 & 1.725883 \\
X2Averaged $\sim \mathrm{e}$ & 603.1168 & 1578.121 & 0.38 & 0.703 & -2524.036 & 3730.27 \\
X3Quantity y & 3.894876 & 3.01982 & 1.29 & 0.200 & -2.089099 & 9.878851 \\
X4Quantity p & -94.30201 & 207.8054 & -0.45 & 0.651 & -506.0822 & 317.4782 \\
X5investment & .2046442 & .0927013 & 2.21 & 0.029 & .0209503 & .388338 \\
X6export & .3274057 & 1.209874 & 0.27 & 0.787 & -2.070041 & 2.724852 \\
X7rateofin n & 864.1775 & 984.6828 & 0.88 & 0.382 & -1087.037 & 2815.392 \\
X8GDP & -.0023551 & .0066019 & -0.36 & 0.722 & -.0154372 & .0107271 \\
_Cons & -16271.43 & 22585.56 & -0.72 & 0.473 & -61026.23 & 28483.36
\end{tabular}

\begin{tabular}{|c|c|c|}
\hline Years & $\begin{array}{l}\text { Market capitalization } \\
(\mathrm{mln} \text {. soum })\end{array}$ & $\begin{array}{l}\text { Market capitalization } \\
(\mathrm{mln} \text {. soum })\end{array}$ \\
\hline 2010 & 26896 & 26896 \\
\hline 2011 & 62098 & 62098 \\
\hline 2012 & 63601 & 63601 \\
\hline 2013 & 70438 & 70438 \\
\hline 2014 & 79788 & 79788 \\
\hline 2015 & 88898 & 88898 \\
\hline 2016 & 103695 & 103695 \\
\hline 2017 & 121728 & 121728 \\
\hline 2018 & 302614 & 302614 \\
\hline 2019 & 442251 & 442251 \\
\hline forecast & & $\begin{array}{c}\text { the optimistic inertial } \\
\text { scenario }\end{array}$ \\
\hline 2020 & 477532 & 419220 \\
\hline 2021 & 512812 & 449981 \\
\hline 2022 & 548093 & 481434 \\
\hline
\end{tabular}

TABLE 5: SCENARIOS FOR THE LEVEL OF STOCK MARKET COVERAGE

According to the calculated optimistic scenario, the capitalization of the stock market in 2020 will amount to 477,532 mil. soums, in 2022 - 548,093 mil. soums. This figure represents a 14 percent increase over the amount calculated under the inertial scenario.

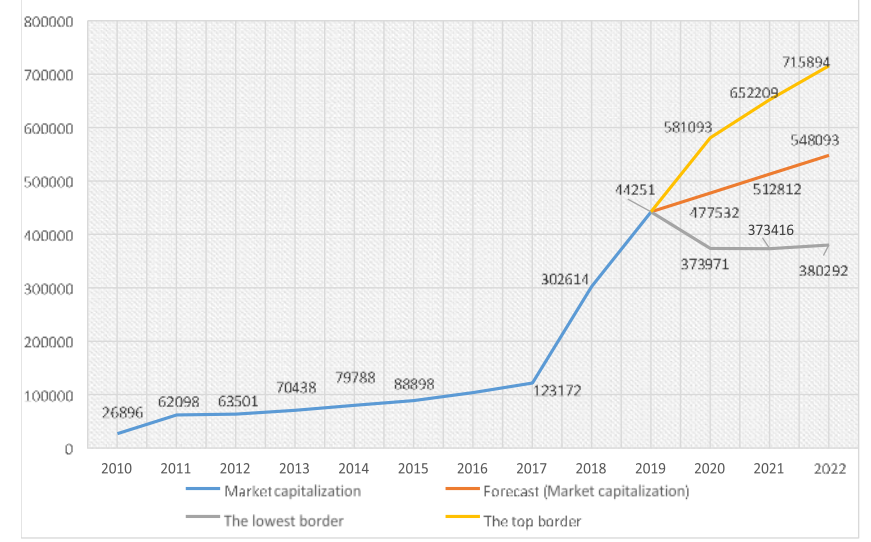

Fig. 3. The optimistic scenario of stock market development in Uzbekistan.

The inertial scenario of the development of the stock market in Uzbekistan is based on the regression equation. 


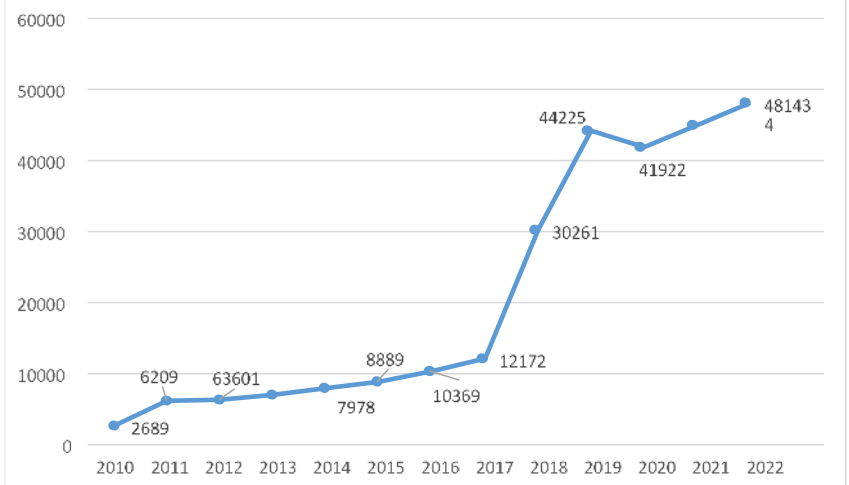

Fig. 4. The inertial scenario of stock market development.

According to this scenario, the capitalization of the stock market of the Republic of Uzbekistan in 2020 will be 419,220 million soums, and in 2022 this figure will be 481,434 million soums.

\section{CONCLUSIONS AND RECOMMENDATIONS}

The research found that with the announcement of the coronavirus pandemic in the international stock markets, there was a sharp decline in trading volumes in the stock markets. This situation, under the influence of future economic uncertainty, has been a serious concern for all market participants for some time. The emergence of a global crisis, the risk of increasing restrictions on logistics and trade, is causing serious socio-economic problems in all countries.

Summarizing the results of the study, the following conclusions were drawn:

Firstly, during the Covid-19 pandemic, the government forecasted a slowdown in GDP growth of $1.8 \%$ in the country (previously, the IMF had forecast Uzbekistan's GDP growth rate of $6 \%$ for 2020) [12]. There are also interruptions in the activities of large joint-stock companies, which have a serious negative impact on the number of dividends, the decline in income.

Secondly, to mitigate the impact of the pandemic on the economy of Uzbekistan, the Anti-Crisis Fund was established under the Ministry of Finance in the amount of 10 trillion soums, which will be used to support sectors of the economy and ensure their stability [13].

Thirdly, as a result of the analysis of various development scenarios, by 2022, the stock market capitalization is expected to reach 548,093 mil. Soums.

We believe that the continuation of institutional changes, in particular, the expansion of the powers of the Capital Market Development Agency to regulate the stock market, further ensure transparency of corporate governance, further improve legislation in this area, increase financial literacy will have a positive impact on stock market development.

\section{REFERENCES}

[1] Wang, C, W. Li, D Drabek, N. M.A. Okba, R. Van Haperen, A D.M.E Osterhaus, J.M. Van Kuppeveld, B. L. Haagmans, F. Grosveld and B. Bosch (2020), "A human monoclonal 1 antibody blocking SARS-CoV2 infection", bioRxiv.

[2] Harvey, C. R. (1989), "Forecasts of Economic Growth from the Bond and Stock Markets", Financial Analysts Journal 45(5): 38-45.
[3] Gilchrist, S., and E. Zakrajsek (2013), "Credit Spreads and Business Cycle Fluctuations", American Economic Review 102(4): 1692-1720.

[4] https://www.weforum.org/agenda/2020/03/stock-market-volatilitycoronavirus/.

[5] https://quote.rbc.ru/news/article/5e734d959a7947b4657c268e

[6] www.marketwatch.com.

[7] www.market.businessinsider.com.

[8] E.I. Nosirov. Koronavurus pandemiyasi inqirozining jaxon iqtisodiyiyotiga ta'siri. "Xalqaro moliya va hisob" ilmiy elektron jurnali. № 3, iyun, 2020 yil. 7-bet.https://uzse.uz/abouts/uzstatistics.

[9] https://csm.gov.uz/uz/faoliyat-natijalari/554-markazning-2018yilning-1-yarim-yillik-faoliyati-natijalari-to-g-risida-axborot.

[10] Haetfelder M., Lozovskaya E., Hanush E. Qimmatli qog'ozlar bozorining fundamental va texnik tahlili. SPb.: Piter, $2005.352 \mathrm{p}$.

[11] I.R. Sulaymonov. COVID-19 munosabati bilan inqirozga qarshi moliyaviy choralar: xorijiy tajriba va O'zbekiston amaliyoti. "Halgaro moliya va hisob” ilmiy elektron jurnallari. № 3, iyun, 2020 yil.

[12] O'zR Prezidiumi "Koronavirus pandemiyasi va global iniroz olatatsion itisodiot tarmoqlariga yaxshi tayyorgarlik ko'rish uchun birinchi navbatdagi chora-tadbirlar turisida" gi farmoni. PF-5969-uyqu, 2020 yil 3 mart. 